Luxembourg Income Study Working Paper No. 265

DISTRIBUTION AND REDISTRIBUTION in POST-INDUSTRIAL DEMOCRACIES

David Bradley Evelyne Huber Stephanie Moller Francois Nielsen John Stephens

May 2001 


\section{Distribution and Redistribution in Post-Industrial Democracies}

David Bradley, Evelyne Huber, Stephanie Moller, Francois Nielsen, and John Stephens University of North Carolina, Chapel Hill

Paper prepared for delivery at the Inequality Summer Institute, Harvard University, June 13-14, 2001.

This draft dated 5/14/2001.

Authors note: We wish to thank David Guilkey for statistical advice on estimation from panel data. 


\begin{abstract}
Distributive Processes in Post-Industrial Democracies

David Bradley, Evelyne Huber, Stephanie Moller, Francois Nielsen, and John Stephens; University of North Carolina, Chapel Hill
\end{abstract}

This paper analyzes the processes of distribution and redistribution in post-industrial democracies. We combine a pooled time series data base on welfare state effort and its determinants assembled by Huber, Ragin, and Stephens (1997) with data on income distribution assembled in the Luxembourg Income Survey (LIS) archive. In the case of the LIS data, we re-calculate the micro-data in order to remove the distorting influence of pensioners on pre-tax, pre transfer income distribution. We examine the determinants of three dependent variables: pre-tax, pre-transfer income inequality, posttax, post transfer income inequality and the proportional reduction in inequality from pre to post tax and transfer inequality. We hypothesized that pre-tax, pre-transfer income inequality would be determined by labor market institutions (union density, bargaining centralization), labor market conditions (unemployment), and economic structures (postindustrialism, third world imports). We hypothesized that the reduction in inequality would be determined by political configurations: directly by left government and indirectly via their effect on welfare state generosity by left government and Christian democratic government. Post tax and transfer income inequality was hypothesized to be a product of the combination of labor market variables and political variables. The results broadly confirms our hypotheses and the overall fit is very good $\left(\mathrm{R}^{2}=.56\right.$ to .80$)$. 
Other than the level of economic development and peace, arguably no economic or political outcome is more consequential to the quality of life of the members of a society than the distribution of disposable income. In this article, we analyze pooled time series data which shed light on the age-old question of politics "who gets what, when, and how" for the case of complex post-industrial democracies with an emphasis on the "who, what, and how." We seek to understand HOW different social strata (WHO) get WHAT share of income. Specifically, we investigate to what extent distribution and redistribution are driven by demographic and economic or by institutional and political variables. This is important not only from a theoretical point of view, but also from the point of view of political practice. Economic and demographic factors are extremely difficult to manipulate, and so are certain institutions, such as labor market institutions. In contrast, partisan composition of government and tax and transfer policies are more amenable to political choice. Thus, if we can demonstrate that partisan composition of government and tax and transfer policies indeed play a crucial role in redistributing resources in society, we lay the responsibility for the degree of inequality in access to material resources squarely on the shoulders of political leaders.

Given that the degree to which governments redistribute income is arguably one of the most consequential outcomes of the political process for citizens' living conditions, it is surprising that there have been so few studies which attempt to explain variation across advanced industrial societies in distributive outcomes and the redistribution process. One might suppose that this topic would have been a major preoccupation of the comparative welfare states literature, but only a handful of cross national studies of the determinants of distributive outcomes have been produced, compared to literally hundreds of studies of social spending. No study has ever attempted to account for variations in the degree to which governments redistribute income. This is odd given that, as Esping-Andersen (1990) observes, governments do not spend money just to spend money but rather to affect an outcome and certainly one of the most important political outcomes is redistribution.

The answer to the paradox of why such important processes have been so little studied is simple: lack of comparable data on an adequate number of cases. For example, the OECD sponsored study by Sawyer (1976) was only able to develop "reasonably comparable" data for ten countries and, by the standards of the Luxembourg Income Survey (LIS), Sawyer's figures were of questionable comparability. ${ }^{1}$ The first wave of LIS studies improved comparability greatly and, unlike the Sawyer study, allowed the researcher to measure how much of the final distributive outcome was due to governmental redistribution (e.g. see Mitchell 1991). However, the number of cases, ten to twelve, was far too small to allow multivariate statistical analyses of the causes of variation in distributive and redistributive processes. Fortunately, the subsequent

\footnotetext{
1 Before the publication of Sawyer (1976), several scholars used the Paukert (1973) income distribution data (e.g. see Hewitt 1977, Cameron 1976, Stephens 1976). After the Sawyer study revealed the incomparability of much of these data, Stephens (1979) used the Sawyer data but dropped multiple regression for simple correlation due to the small number of cases, while Cameron (1978) dropped the income distribution section of the earlier APSA paper.
} 
development of the LIS data archive - expanding of the number of countries covered and the time points for which there is available data - now makes such analyses possible.

In this article, we examine the determinants of distributive and redistributive processes in post-industrial democracies using three measures calculated from the LIS data as dependent variables: pre-tax, pre-transfer income distribution, posttax, post transfer income distribution and the proportional reduction in inequality from pre to post tax and transfer inequality. We hypothesize that the measures of market and final income distribution and of reduction in inequality will be determined by different combinations of labor market institutions (union density, bargaining centralization), labor market conditions (unemployment), economic structures (post-industrialism, third world imports), and political configurations (left government and Christian democratic government). We expect political configurations to shape resdistribution both directly and indirectly via their effect on welfare state generosity.

\section{Literature and Hypotheses}

The dates and countries of the available LIS studies strongly shape the literature and the range of hypotheses relevant to our analysis. First, since one of our purposes is to examine the impact of the welfare state on redistribution, we limit our study to the 18 advanced industrial countries that have a population of one million or more and have been democracies since World War II. This is the usual universe of cases studied in quantitative studies of the development of the welfare state. There are LIS studies available for 16 of these countries, 14 of which are included in this study. ${ }^{2}$

Second, the earliest LIS studies date back to the late 1960s, and 54 of the 61 surveys were done after 1975. Thus, these countries were in transition from industrialism to post industrialism, which makes a large body of literature on income distribution, notably work on the inverted U-shaped Kuznets curve relating inequality with economic development (e.g. see Kuznets 1955; Nielsen 1994; Nielsen and Alderson 1995 and literature therein) and World System and dependency studies (e.g. see Bornschier and Chase-Dunn 1985; Alderson and Nielsen 1999 and literature therein) irrelevant for our study.

We draw primarily on the recent literature on the comparative political economy of the welfare state and labor market institutions for our main hypotheses. However, we begin by reviewing the two recent analyses of pooled cross sections and times series data on income inequality in advanced capitalist democracies in order to situate our own work, Gustafsson and Johanson (1999) and Alderson and Nielsen (2001). Both confirm Stephens' (1979) finding that union organization is a strong determinant of income distribution, high levels of unionization being associated with less inequality. In addition, Gustaffson and Johanson find strong positive effects of deindustrialization and youth proportion of the population on inequality and significant but more modest negative ones of public sector size. Alderson and Nielsen find strong positive effects of

2 The one Austrian LIS survey and the one Irish survey were excluded due to missing data. 
agricultural employment and negative ones of Esping-Andersen's decommodification index on inequality and more modest positive ones for third world imports and direct investment outflow.

Our study differs from these two studies in two important ways. First, we break down the distributive process into two stages and analyze the determinants of the pre tax and transfer (or market) income inequality and the reduction in inequality separately. Though we do provide an analysis of post tax and transfer income inequality in order to compare our findings with these two studies, our focus is on the two distinct stages rather than the final outcome. Second, we take advantage of the fact the LIS micro data are available for analysis, and we calculate our own measures of the dependent variable. Most importantly we limit our analysis to the working age population, which allows us both to eliminate the distortion in measures of reduction in inequality created by the inclusion of the aged population (see below) and to measure cross income group (rather than age group) distribution and redistribution more precisely. This is crucial because it addresses one of the most prominent critiques of the welfare state made from a critical left view point, that welfare states are at best redistributive across age groups but not across classes.

We draw our primary hypotheses from power resources theory and its extension, power constellation theory (Rueschemeyer, Stephens, and Stephens 1992, Huber and Stephens 2001), and from recent research on bargaining systems and wage dispersion. Neo-marxist power resources theory (Korpi 1983, Stephens 1979) and its predecessors (Lenski 1966: 316-25, also see Hewitt 1977) argue that distributive outcomes are a product of power relations in society. In advanced capitalist democracies, power resources theory predicts that variations in distribution are a product of variations in working class power; in union strength, socialist party strength, and left government. As we do here, Stephens (1979) breaks the distributive process into two stages. He argues that variations in pre tax and transfer income are products of variations in union strength. In his view, the size and structure of the welfare state determine the degree of governmental redistribution. On the basis of his crossnational analysis, he argues that there are two paths to high welfare state generosity, a catholic and a social democratic corporatist one. He argues that the social democratic corporatist one is much more redistributive.

Huber and Stephens (2000, 2001) considerably refine this view, especially on the determinants of welfare state size and structure. In pooled time series analyses of annual data for 26 countries for 26 time points, they show that the main determinants of variation in eight different indicators of aspects of the welfare state are social democratic government, Christian democratic government, and constitutional structure veto points, with more modest effects of unemployment and female labor force participation. The availability of a number of veto points in a country's constitutional structure depresses welfare state expansion because it enables relatively small groups to obstruct legislation. By the same token, it also slows welfare state retrenchment by enabling losers to block cut-backs. Christian democracy is more strongly related to transfers payments and transfer heavy measures of welfare state effort, while social democracy is more strongly related to measures tapping service provision. Based on a crossnational analysis of LIS 
data on 16 countries, Huber and Stephens (2001) offer the tentative conclusion that social democracy but not Christian democracy has an effect on government reduction in inequality and post tax and transfer inequality. Given the small sample size, they do not test for a full range of alternative causal and control variables. On the basis of these findings, then, we hypothesize that political composition of government affects redistribution indirectly through welfare state generosity, but that there remains a direct political effect on redistribution.

Recent literature on wage bargaining institutions and wage dispersion argues that centralized bargaining results in less wage dispersion (e.g. see Iversen 1996, Wallerstein 1999, and Pontusson et al. forthcoming). Both Wallerstein's (1999) and Pontusson et al.'s (forthcoming) analyses of pooled time series data on wage inequality do show very strong effects of wage bargaining systems on wage dispersion among full time employed workers. Based on these studies, we expect to find at least moderately strong effects of bargaining centralization on pre tax and transfer household income distribution.

Unemployment should increase pre tax and transfer inequality and, to the extent that welfare state benefits do not replace work income, it should also affect post tax and transfer inequality. ${ }^{3}$ The hypothesized effect of unemployment on the reduction in inequality is, at first blush, counterintuitive: To the extent that welfare state benefits replace work income, it should increase redistribution. That is, in the presence of unemployment benefits (which all of these countries have) and other income replacements for unemployed workers (which most of them have), higher unemployment will be associated with more redistribution, ceteris paribus.

The literature on the impact of post industrialism and globalization on inequality suggests several additional hypotheses (Nielsen and Alderson 2001). The transition from an industrial to a service economy is associated with increasing inequality as wages are lower and more dispersed in the service sector due to the low levels of labor productivity in personal and social services (Bluestone and Harrison 1982). Imports from developing countries should increase wage dispersion as they put downward pressure on the wages of low skilled workers who work in industries competing with these imports (Wood 1994). Increased international capital flows and, to a lesser extent trade flows, have been hypothesized to increase inequality for a variety of reasons. Increased capital mobility increases the power of capital vis à vis government and labor, making it possible for capital to use the threat of exit to demand tax concessions from governments and wage concessions from organized labor. Competition with imports and for export markets enables capital to persuade labor to restrain wages in order to preserve jobs.

\footnotetext{
${ }^{3}$ Note that our dependent variable is household income and includes the households of the unemployed. Thus, the inverse relationship between wage dispersion and unemployment noted by Wood 1994 and Esping-Anderson 2001 would not be expected in our data. They explain this inverse relationship with the argument that in countries offering high unemployment benefits, unemployed workers will be more likely to prefer unemployment (with attractive benefits) rather than accept low paying jobs, while in countries with few benefits workers have no other choice than accepting these low paying jobs
} 
Development, usually operationalized as GDP per capita in constant dollars, has been included as a causal variable in almost all studies of income distribution. For studies that include developing countries or long time series on advanced industrial countries stretching back into the early part of the twentieth century, the key hypothesis was the Kuznets inverted U curve. For their study of both industrializing and deindustrializing societies, Nielsen and Alderson (1995) hypothesize (and find) a U curve in which inequality continues to fall in mature industrial societies but then increases with the onset of post-industrialism and globalization (see also Alderson and Nielsen 2001). As we pointed out above, our sample of countries and time points falls into the postindustrial category, thus one would expect a trend to increasing inequality with rising per capita income. However, it is unclear that rising income per se independent of the associated processes of deindustrialization and globalization outlined in the previous paragraph should be associated with greater inequality. ${ }^{4}$

Considered as a labor market variable, female labor force participation has been hypothesized to both increase or decrease inequality by different authors (Thurow 1987; Cancian, Dantziger and Gottschalk 1995; Nielsen and Alderson 1997). To further complicate the picture, female labor force participation has been shown to result in political mobilization of women, in shifting preferences of women toward left parties, and in greater demands for welfare state transfers and services (Huber and Stephens 2000, 2001). Pulling these two literatures together, we hypothesize positive effects of female labor force participation on reduction of inequality and negative effects on income inequality, particularly post tax and transfer inequality.

Following the lead of previous LIS researchers, we adjust household income for household size (see below). Thus, if there is a negative association between household income and fertility, as is often the case, there will be a positive association between the proportion of the population that are young and inequality.

In closing, we note that many of the variables that have been hypothesized to affect income inequality have no necessary relationship to governmental reduction in inequality. Given the absence of a theoretical justification for their inclusion, we do not include per capita income, proportion young, third world imports, and post industrialism in our analysis of reduction in inequality.

\section{Measures of Dependent and Independent Variables}

The measures of inequality come from the Luxembourg Income Study (LIS) database, which provides the most comparable income and earnings data available

\footnotetext{
4 We should note that globalization is causally related to the development of the world economy but simply associated with (and not causally related to) rising per capita GDP in individual countries. Thus, for example, in the mid 1990s, economic actors and policy makers in the US and the UK are facing the same pressures from open financial markets despite quite different levels of per capita GDP. By contrast, post industrialization is primarily a property of the domestic economy, thus there is a stronger causal link between the development of the domestic economy and post industrialism than between domestic economic development and globalization.
} 
across a large number of OECD countries. ${ }^{5}$ LIS collects data from national microdata (i.e. survey data based on individual level data rather than macro aggregates) sources and harmonizes the data sets to make income comparisons across countries and over time possible. Currently, there are survey data available for 25 countries, and over time points ranging from 1 year to 7 years per country. LIS data are arranged by waves, with the first starting in the late 1970s and the most recent wave in the mid to late 1990s. There also exist historical data (pre-1979) for a handful of countries. The collection and harmonization of data in waves means that LIS data can be used to look at income trends, rather than single points in time only. The LIS surveys provide the best available comparable cross-national, over time data source for income in OECD countries. In a comparison of reported income data (from surveys, the source of LIS data) with external aggregates (e.g. national accounts, income tax data), the OECD found that ratios of survey based data to national accounts based data normally fall in the 80-90\% range (OECD 1995). In other words, the advantages one gains by using survey data (i.e. detailed demographic information), rather than national accounts, does not seem to come at a high cost in terms of data quality for income. Even national microdata sources change over time, due to altering of the sampling method, question formulation, etc. The LIS project draws on a variety of microdata sources - income surveys, administrative and income tax records, panel studies, expenditure surveys, and labor force survey supplements - to create income and demographic variables at both the household and individual level.

The income inequality figures published on the LIS web site and in the many publications using the LIS data are not adequate for our purposes, as they include pensioners, which distorts the pre tax and transfer inequality and exaggerates the reduction in equality, as mentioned above. In countries with comprehensive public pension systems, such as the Nordic countries, which give the pensioner a replacement rate which is often three quarters of his or her working income, pensioners make little other provision for retirement. For instance, in an analysis of LIS data, Mäkinen (1998) finds that $93 \%$ of Finns and $89 \%$ of Swedes are poor before transfers and only $4 \%$ and $2 \%$ are poor, respectively, after transfers are added in. Thus, pre tax income inequality (and poverty) will be artificially high and the reduction in equality also exaggerated. ${ }^{6}$ In order to avoid this distortion, we conducted our own analysis of the LIS micro data excluding those over 59 and under 25 . This excludes most early pensioners and students as well, so the remaining population is clearly working age.

We constructed three measures: pre tax and transfer inequality, post tax and transfer inequality, and reduction in inequality effected by taxes and transfers (see Tables 1 and 2). For our measure of inequality we chose the gini coefficient. The gini coefficient is a measure of income distribution based on plotting the share of households in a given setting (in this case a country) against the cumulative share of income. The gini coefficient ranges from zero to one. With complete equality in society (all

\footnotetext{
5 See http://www.lis.ceps.lu for a general introduction to the LIS database and a complete list of countries, years, and variables available in this rich data source.

6 To take one example, Mitchell calculates that taxes and transfers reduce inequality among the population of surveyed Swedes in 1981 by 53\%, whereas our calculations for the population 25-59 show a 34\% reduction in equality.
} 
households having an exactly equal share of income) the gini coefficient would equal zero; similarly, if one household held all the income the gini would equal one. A lower gini coefficient indicates greater equality. There are several choices facing users of microdata in terms of how to calculate income variables. As discussed above, we restrict our measure of inequality to households with a head aged 25 to 59 years old to reduce the distorting effects of pensioners and students on the distribution of income. The pre tax and transfer gini calculations are based on market income. This is the total income from wages and salaries, self-employment income, property income, and private pension income. The post tax and transfer gini is based on disposable personal income. This includes all market income, social transfers, and taxes. ${ }^{7}$ Both market income and disposable income figures were bottom coded at $1 \%$ of mean income adjusted for household size and composition. Because we are using an income concept based on households, adjustments had to be made for household size. Equivalence scales are used to adjust the number of persons in a household to an equivalent number of adults. If one chooses not to use an equivalence scale, one ignores the economies of scale resulting from sharing household expenses and assumes that each additional equivalent adult in a household has the same "cost" as other members of the household. We choose a commonly used scale of the square root of the number of persons in the household (see OECD 1995 for a discussion of equivalence scales).

\section{\{Tables 1 and 2 about here $\}$}

Our exclusion of pensioners and youth from the analysis has an additional great advantage from the point of view of the comparative welfare states literature. In critiques of the welfare state, it is often claimed that welfare states effect only life cycle redistributions of income and not redistribution across income classes. By limiting the analysis to the working age population, we assure that our measure does measure redistribution across income groups. As one can see from Table 2, the reduction in inequality effected by taxes and transfers is substantial and the cross national variation in the reduction is also great.

Our proposed measure of welfare state effort is strongly conditioned by the nature of the LIS data. The LIS post tax and transfer income distribution data measure disposable cash income. No effort was made to estimate the redistributive effects of the provision of free or subsidized public goods, a dimension of the welfare state on which the social democratic welfare state is most distinctive. Thus, variations in the funding and delivery of social services have no obvious effect on the measures of reduction in inequality and post tax and transfer inequality we have calculated from the LIS data. Our measure of welfare state effort, "Taxes and Transfers", is the sum of the standard scores for total taxes as a percentage of GDP and transfer payments as a percentage of GDP (see Table 1). We standardize the two measures in order to weigh them equally.

We coded the political variables, left-party government share and Christian democratic party government share, as " 1 " for each year that these parties were

\footnotetext{
${ }^{7}$ See http://lisweb.ceps.lu/techdoc/variabdef.htm for a summary of LIS income variables.
} 
in government alone, and as a fraction of their seats in parliament of all governing parties' seats for coalition governments. Our measure of veto points created by the constitutional structure is an additive index of federalism (none, weak, strong), presidentialism (absent, present), bicameralism (absent, weak, strong), and the use of popular referenda as a normal element of the political process (absent, present). Thus, a high score indicates high dispersion of political power and the presence of multiple veto points in the political process.

We considered a number of different measures of globalization: trade openness, inward and outward direct foreign investment, borrowing on international capital markets, imports from third world countries, and Quinn/Inclan measures of capital and current account controls. The specificity of the hypothesis on the effect of third world imports argued for the inclusion of this variable. For a more general measure of economic openness, we favored the control measures over the flow measures because, as Simmons (1999) and others have argued, it is the possibility of easy exit that changes the behavior of actors not variations in actual flows. To take two examples, in the absence of capital controls, (1) interest rates should equalize because capital will flow out of countries with low interest rates, and (2) domestic capital will be empowered vis à vis labor and government because it could exit were its demands not met. Thus, we selected the Quinn/Inclan measure of capital controls, in which the maximum score indicates no capital controls, as our general measure of economic openness. In fact, this measure was most strongly correlated with our inequality measures of the available globalization measures.

For union density, we use union membership as a percentage of total wage and salary earners (Ebbinghaus and Visser 1992). Our industrialism measure is percent of the labor force employed in industry. ${ }^{8}$ The bargaining centralization measure is Iversen's measure which weighs the level at which bargaining takes place (plant and firm level, industry level, national level) by the number of workers covered by agreements at that level. A higher score indicates more centralized bargaining. We also considered two other measures of labor market institutions which Wallerstein (1999) found to be strongly related to wage dispersion, the level of wage setting and the Herfindahl index of concentration within confederations. The Iversen measure is preferable to Wallerstein's level of wage setting measure for our purposes because the Wallerstein measure combines bargaining centralization with interventions by governments to set wages, and we want to keep the effects of politics and labor market institutions separate in so far as possible. However, we did cross check our results using these measures in place of Iversen's index and they performed no better on the pre tax and transfer inequality on which we expected strong effects of labor market institutions.

The operationalizations of percent of the total labor force unemployed, female labor force participation, and percent of the population under 15 are selfexplanatory. Fourteen of the eighteen large advanced industrial countries which have

${ }^{8}$ The Alderson and Nielsen (2001) results suggest that we should also include the percentage of the population in agriculture as an independent variable. We did test this hypothesis but it did not have the hypothesized effect in our data, which do not reach as far back in time as their data. The agricultural section is very small in all of our countries by this point in time (mean $=5 \%)$. 
been democracies since World War II are included in the analysis. New Zealand and Japan are excluded as there are no LIS surveys for these countries. The one Austrian LIS survey is excluded due lack of LIS data for pre tax and transfer inequality and the one Irish LIS survey is excluded due to missing data on bargaining centralization. The average values for the dependent variables and some of the independent variables are listed by country grouped by welfare state regime in Table 2.

\section{Estimation techniques}

Unbalanced panel data and correlated errors

We use an unbalanced panel data set with 61 observations on 14 countries, with countries providing different numbers of observations according to data availability, with a minimum of 1 and a maximum of 7 observations per country. The time span between observations is irregular, varying across countries and time points. A central problem in estimating regression models from panel data is that the assumption of independence of errors across observations is unlikely to be satisfied. As a result OLS produces incorrect standard errors for the regression coefficients (e.g., Hsiao 1986; Greene 1993).

There are several strategies to deal with correlated errors in panel data. One popular approach (exemplified by the Parks method) assumes unit specific serial correlation of the errors, as in a classical time series. As pointed out by Beck and Katz (1995:635-4) the Parks method and its extensions require what Stimson (1985) calls temporally dominated time series of cross sections, i.e. data structures consisting of relatively few units observed over many equally spaced time points. The small number of time points and the unequal spacing of observations in our data set do not support estimation of an autoregressive process. Another major approach is to estimate a random effect model (REM) in which the error term contains a unit specific component that differs across units (countries) but is constant over time for a given unit. Such an error structure would arise if unmeasured unit specific causes (such as systematic measurement differences, or aspects of the history or culture of a country) affect the dependent variable in the same way at each point in time over the period of the data. The stable unit specific component implies that observations for the same unit at different time points are all correlated by the same amount Rho. The REM strategy is feasible in this situation, and it allows estimating the value of Rho. But REM requires relatively strong assumptions and may not be optimal given the small sample size.

We chose an estimation approach that is appropriate to an estimation situation (like the present one) in which it is not essential to measure the correlation Rho of the errors pertaining to the same unit and that necessitates minimal assumptions on the behavior of the errors. It consists in combining OLS estimation of the regression coefficients with the Huber-White (or "sandwich") robust estimator of the standard errors. The robust estimator takes into account the correlations among errors associated with the "clustering" of observations pertaining to the same country (see the discussion in StataCorp 1999, User's Guide pp. 256-260). As an additional check we also estimated 
the models using a variant of the generalized linear model, available in the program STATA as procedure xtgee, that is equivalent to feasible generalized least squares estimation of the REM. In the discussion of the results we report when the OLS and REM estimates are substantially different.

Collinearity

As Huber, Ragin, and Stephens (1993) point out, collinearity is a serious problem in these data. Left cabinet, union density and bargaining centralization are highly intercorrelated which is not surprising since they are causally interrelated. Adding our taxes and transfers measure adds to the problem, as we tried to add it to regressions that include its own determinants including, among others, left cabinet. Left cabinet is at the center of this nexus; it is strongly correlated to union density (.80), bargaining centralization (.66), and taxes and transfers (.54). We set 5 as the maximum tolerable level of the variance inflation factor (VIF). This is more restrictive that the conventional 10 (though less so than Huber et al.'s, 1993 suggested level of 4) but we find considerable coefficient instability with variance inflation factors of greater than 5 (or tolerance levels of .2). With the selected VIF level, even the correlation between left cabinet and union density was not a problem in and of itself. Rather it was the multiple correlations between the causal and control variables that posed the problem. In the case of the reduction in inequality dependent variable, with the more limited range of control variables, this was easily solved by running the equation without union density and then substituting union density for left cabinet in the final equation to test whether it performed as well.

In the case of the models for the two inequality variables, we first regressed each dependent variable on control variables, the labor market institution variables, and the political variables separately. We then regressed the dependent variable on all variables that were significant at the rather tolerant .1 level (to make sure that we did not pass over potentially significant variables) in the separate equations. We then reduced the equation using the .1 criterion to eliminate variables and then used the conventional .05 level to assess significance in the final equation.

\section{Results}

Table 3 displays the results of the regressions for pre tax and transfer inequality. Equations 1-3 regress the dependent variable on controls, labor market institutions, and the political variables, respectively. Regression 4 presents the results of the regression with all variables significant at the .1 level or better in the first three equations, and regression 5 the reduced equation. As indicated by the $\mathrm{R}^{2}$, the fit is very good. By far the most surprising result was the absence of any significant effect of bargaining centralization on pre tax and transfer inequality. This is not an artifact of the particular measure we used; we got the same insignificant results using the two measures used by Wallerstein (1999) in his study of wage dispersion. Unemployment, youth proportion of the population, and union density all have the hypothesized moderate to strong effects on the dependent variable. 
\{Table 3 about here $\}$

GDP per capita had a somewhat stronger effect than we expected based on past studies, suggesting that post industrialism and globalization have had strong inegalitarian effects. In equation 6, we test whether the effect of GDP per capita can be attributed to the processes hypothesized above, deindustrialization, growing financial openness, and third world imports. While the variation explained by the two equations is similar and the three variables are correctly signed, none of them are significant. The REM estimates were consistent with the OLS results.

Table 4 presents our results for the analysis of governmental reduction in inequality. In order to eliminate multicollinearity, union density was eliminated from the first equation. Equation 2 presents the reduced version of the first equation, while equations 3 and 4 substitute left cabinet and union density for bargaining centralization. The variation explained by equations 2-4 is impressive, indicating an extremely good fit with the data. As hypothesized, the variations in the magnitude of taxes and transfers have a very powerful effect on variations in the reduction in inequality. The zero order correlation between these two variables is an impressive .68. This result clearly demonstrates the crucial importance of a generous welfare state for redistribution across income classes. As hypothesized, unemployment has a positive effect on governmental reduction in inequality. In countries with generous unemployment benefits, support for retraining, etc., higher unemployment results in more redistribution. Bargaining centralization, left government, and union density all have the hypothesized positive effects on inequality reduction. The variation explained by the three equations is sufficiently similar that it is difficult to make a statistical case for the superiority of one of these three closely interrelated variables over the others. However, from comparative historical evidence we know that the crucial decisions about the structure of major welfare state programs were always taken by parliaments and that strong labor movements, such as the Austrialian, were not capable of building generous welfare states in the absence of incumbency of left-wing parties (Huber and Stephens 2001). In the REM estimates, Christian democratic government fell short of significance in equations with left cabinet and union density.

\section{\{Table 4 about here $\}$}

Clearly, the welfare state is the main policy tool available to governments to redistribute resources. Thus, we might expect the entire effect of partisan government to be captured by taxes and transfers. However, our measure only captures the magnitude of taxes and transfers, and the remaining direct effect of partisan incumbency once magnitude is taken into account draws attention to the differences in structures of tax and transfer systems. Obviously, tax systems vary greatly in their degree of progressivity, and the allocation of transfers can be more or less skewed towards lower income groups. Social democratic governments have favored more progressive tax systems and transfers more heavily directed towards lower income groups, whereas Christian democratic governments have been less intent on shaping their tax and transfer systems in a redistributive direction. If we were able to include measures for the structure of tax and transfer systems in our analysis, then we would expect the entire effect of political 
incumbency to be absorbed by the measures of the magnitude of taxes and transfers and their structure.

Even such a measure would not capture the entire redistributive effect of social democratic governments because of limitations in our dependent variable. Our dependent variable only measures income, and not the value of free or subsidized public services. Social democratic governments have expanded a variety of public services, from public health care, child care and elderly care, to training and retraining, access to which is either universal and free or to be paid for according to income. With the partial exception of health care, Christian democratic governments have preferred private delivery of such services - to the extent that the state became involved in supporting them at all - and payments according to insurance principles, which has a less redistributive effect. ${ }^{9}$

It is worth pointing out here that our results indicate that all types of welfare states are redistributive, including the liberal welfare states. However, since magnitude of taxes and transfers strongly influences the degree of redistribution achieved, and since the north-western Christian democratic welfare states (Belgium, Netherlands, France) are markedly more generous, these welfare states have a stronger redistributive effect than the liberal welfare states (Table 2). In fact, a visual inspection in Table 2 of the magnitude of and the total redistribution effected by liberal and Christian democratic welfare states suggests that the structure of the liberal welfare states is more redistributive than the structure of the Christian democratic welfare states. This is largely a result of the heavy reliance on means testing and the limits of earnings-related benefits characteristic of liberal welfare states.

While we expected Christian democratic government to have a negative effect on reduction in inequality net of its positive effect on taxes and transfers, we did not expect an effect of this magnitude. We can explore this further by examining the determinants of our taxes and transfers measures. We regressed the tax and transfer variable on the five variables which Huber and Stephens (2001) found to be the consistently most important determinants of eight different measures of welfare state generosity: Christian democratic cabinet, left cabinet, constitutional structure, female labor force participation, unemployment, per capita GDP and percent aged. Reducing the equation by eliminating independent variables not significant at the .1 level produced the following:

Taxes $\&$ Transfers $=.43$ Christian democratic cabinet +.69 Left cabinet +.32 Unemployment

The coefficients are standardized (or path) coefficients and the $\mathrm{R}^{2}$ is .63 . With this equation and equation 3 in Table 4, we can calculate the indirect effects of Christian democracy and social democracy on reduction in equality via taxes and transfers and add it to the standardized coefficient to get an estimation of the total effect on reduction in inequality. The indirect effect of social democracy via taxes and transfers is .41, giving a total effect of .73. The indirect of effect of Christian democracy via taxes and transfers is

\footnotetext{
${ }^{9}$ Education is delivered primarily by the public sector in all of these countries except the Netherlands.
} 
.27 giving a total effect $-.18 .^{10}$ This effect is small enough in size to warrant the interpretation that the overall effect of Christian democratic incumbency is distributionally neutral. These causal processes are graphical represented in Figure 1. Given the cross-class base of Christian democratic parties and their project of mediation and reconciliation of interests (van Kersbergen 1995), this is not surprising. Christian democratic parties favor the welfare state because they want to offer generous safety nets for people in all income groups, not because they want to redistribute income. To the extent that the structures of Christian democratic welfare states contain redistributive features, these tend to be the result of social democratic influence. The competition with strong left-wing parties has forced Christian democrats to make concessions that have generally enhanced redistribution.

\section{\{Figure 1 about here}

For purposes of comparison to other recent pooled time series studies of income distribution, let us briefly summarize the results of our analysis of the post tax and transfer inequality. Using the same procedures we used in the case of our analysis of pre tax and transfer inequality, we came up with the following equation: ${ }^{11}$

Post inequality $=28.30+.257$ GDPPC -.132 Union -.852 Taxes $\&$ Transfers

$\begin{array}{llll}\text { Standardized } & .31 & -.60 & -.33\end{array}$

$\mathrm{R} 2=.73$

Like Alderson and Nielsen (2001) and Gustafsson and Johanson (1999), we find that union density and a measure of welfare state effort or public size are important determinants of inequality. Like Alderson and Nielsen, we find that GDP per capita is related to inequality though again our analysis only captures the upswing side of their $U$ curve. Substituting capital market openness, third world imports, and deindustrialization for GDP per capita (not shown), we find that though the overall fit is as good as the equation above and all three variables are correctly signed, only the coefficient for capital market openness is significant. Substituting left government or bargaining centralization for union density resulted in a poorer fit with the data.

\section{Conclusion and Discussion}

In this paper, we break new ground in the study of variations in the distributive outcomes in post industrial democracies by dividing the distributive process into two stages, the distribution of pre tax and transfer income and the reduction in inequality effected by taxes and transfers. Our first contribution arises from the mere computation of the dependent variables, particularly reduction in inequality. We demonstrate that the assertion that the welfare state merely redistributes income across

${ }^{10}$ The total effects of Christian democracy and social democracy are very similar to the results one gets if one drops Taxes and Transfers from equation 3 in Table 4 . The standardized coefficients for social democracy and Christian democracy are. 74 and -.18 respectively. The latter coefficient is not significant. 11 The REM estimates were consistent with the OLS estimates. 
generations is wrong. All types of welfare states, even liberal welfare states, redistribute income across income groups. However, there is great variation in time and space in the proportional reduction in inequality from the extremes of Switzerland in 1982 with only a $6.2 \%$ reduction in inequality to Sweden in 1995 with a $47 \%$ reduction in inequality.

We then examine the determinants of the two stages separately and indeed find that they are quite different. High pre tax and transfer inequality is associated with high unemployment, high per capita GDP, high proportions of youth in the population, and with low union density. By contrast, political variables, directly or indirectly via their effect on the volume of taxes and transfers, figure strongly among the determinants of reduction in inequality. The importance of partisan politics is particularly great if one selects equation 3 (with left cabinet) rather than equation 2 (bargaining centralization) or 4 (union density) as the appropriate causal model. As we have seen, there is no statistical reason to do so. There is, however, comparative historical evidence which points very strongly in the direction of left cabinet and not union density or bargaining centralization. Huber and Stephens (2001: Chapter 5) investigate this question extensively and conclude that neither union organization nor bargaining centralization (which in this case can be taken to be an indicator of corporatism) had much effect on social policy independent of the partisan composition of government.

Thus, our equation 3 can be taken to be the best estimate of the determinants of reduction in inequality. This equation and the estimations of indirect effects of left and Christian democratic government via their effect on taxes and transfers yield our most important and striking finding: left government very strongly drives the redistributive process directly by shaping the distributive contours of taxes and transfers and indirectly by increasing the proportion of GDP devoted to taxes and transfers. By contrast, the direct and indirect effects of Christian democratic government are actually negative though not strongly so. Huber and Stephens (2001) and Swank (forthcoming) have taken Esping-Andersen to task for his characterization of Christian democratic welfare states as preserving inequality. From the marginals on governmental redistribution in Table 2 one can see that they do not (nor do other types of welfare states). But if we can agree with Swank and Huber and Stephens that the distributive outcomes in Christian democratic welfare states are more egalitarian than in liberal welfare states, our analysis shows that this is the case because they have stronger unions or longer periods of left government and not because of Christian democratic governance.

As we pointed out in our discussion of previous studies of the determinants of variations in inequality in industrial and post industrial democracies, union density has been repeatedly found to be a determinant of post tax and transfer inequality, overwhelming left government where these two variables have been tested against one another as in this study and Stephens (1979). The conclusion from this finding would appear to be that labor market institutions and not politics are decisive for the final distributive outcomes. By breaking the distributive process into two stages, one sees how wrong this interpretation is. Union density is an important but not overwhelming determinant of pre tax and transfer inequality while left government is an overwhelmingly strong determinant of governmental redistribution. Union density's strong effect on post tax and transfer inequality is a product of its strong relationship with 
left government $(\mathrm{r}=.80)$. Most of its effect on the final distributive outcome is via its effect on left government.

In comparing our results to those of Aldersen and Nielsen, one finds that when we replaced GDP per capita with deindustrialization and globalization variables (as they did) the overall fit was as good and the signs were correct but five of the six coefficients fell short of significance in the two regressions. This was almost certainly a product of sample size, as the Aldersen and Nielson study covers three times the number of cases due primarily to the greater number of time points. Thus, we would expect confirmation of the globalization and deindustrialization hypotheses with data comparable to the LIS surveys but with a greater number of time points.

Given the strong relationship between bargaining centralization and wage inequality found by Wallerstein (1999) and Pontusson et al. (forthcoming), the absence of a significant relationship between bargaining centralization and pre tax and transfer inequality came as a surprise. Since our data are household income and thus include not only full and part time work income in the same household but also property income, while the wage dispersion data are for full time individual employees, one might not expect as strong a relationship. Still, the absence of any significant relationship is puzzling and needs further investigation.

The results for unemployment follow the conventional expectations for pre tax and transfer inequality: more unemployment leads to more inequality. For the other two variables, the results were not so obvious and say something rather new about distributive processes in the welfare state. The positive effect of unemployment on reduction in inequality was an easily resolved paradox: All of these countries had unemployment compensation systems, so while unemployment raised pre tax and transfer inequality, unemployment compensation lowered it and thus the reduction in inequality was greater where and when unemployment was higher. The result for post tax and transfer inequality was even more interesting: No significant effect of unemployment on inequality. We attribute this to the comprehensiveness of unemployment social protection in the Christian democratic and social democratic welfare states and sufficient adequacy in the liberal welfare states. Aaberge et al.'s (1999) longitudinal study of annual data on income distribution in Nordic countries with data comparable to LIS data showed almost no effect of the unemployment crises of the 1980s and 1990s on post tax and transfer income inequality, which is a tribute to the comprehensiveness of Nordic unemployment social protection systems.

Taken together, the results of our study are a resounding vindication of power resources theory (Korpi 1983, Stephens 1979) and its predecessors (Lenski 1966) and its extensions (Huber and Stephens 2001). These theories hypothesize strong relationships between distributive outcomes and working class strength whose expressions are union movement strength, left party mobilization, and left party governance. The important role of union organization in influencing variations in distributive outcomes underlines the findings of previous studies. The decisive role of left government in determining variations in governmental redistribution is a new finding which supports a central hypothesis advanced by these theories. 


\section{References}

Aaberge, Rolf, Anders Börklund, Markus Jäntti, Peder J. Pedersen, Nina Smith, and Tom Wennemo. 1999. "Unemployment and Income Distribution: How did the Nordic Countries Fare during their Crises." Scandinavian Journal of Economics 101.

Alderson, Arthur S. and François Nielsen. 1999. "Inequality, Development, \& Dependence: A Reconsideration." American Sociological Review 64:606-631.

2001. "Globalization and the Great U-Turn: Income Inequality Trends in 16 OECD Countries." Presented at the Re-Inventing Society in a Changing Global Economy conference at the University of Toronto, Ontario. 8-10 March.

Beck, Nathaniel and Jonathan N. Katz. 1995. "What To Do (and Not To Do) With Time-Series Cross-Section Data." American Political Science Review 89:634-47.

Bluestone, Barry and Bennett Harrison. 1982. The Deindustrialization of America. New York: Basic Books.

Bornschier, Volker and Christopher Chase-Dunn. 1985. Transnational Corporations and Underdevelopment. New York: Praeger.

Cancian, Maria, Sheldon Danziger and Peter Gottschalk. 1993. "Working Wives and Family Income Inequality Among Married Couples." in Danziger, Sheldon and Peter Gottschalk (eds.) Uneven Tides: Rising Inequality in America. New York: Russel Sage Foundation.

Ebbinghaus, Bernhard and Jelle Visser. 1992. "European Trade Unions in Figures." Manuscript. University of Amsterdam, Department of Sociology.

Esping-Andersen, Gosta. 1990. The Three Worlds of Welfare Capitalism. Princeton: Princeton University Press.

2001. "Postindustrial Cleavage Structures: A Comparison of Evolving Patterns of Social Stratification in Germany, Sweden, and the United States." Pp. 697-707 in Social Stratification in Sociological Perspective. $2^{\text {nd }}$ edition, edited by David B. Grusky. Boulder, CO: Westview Press.

Greene, William H. 1993. Econometric Analysis. (2 $2^{\text {nd }}$ edition.) Englewood Cliffs, NJ: Prentice Hall.

Gustafsson, Bjorn and Mats Johannson. 1999. "In Search of Smoking Guns: What Makes Income Inequality Vary Over Time in Different Countries?" American Sociological Review 64: 585-605. 
Hewitt, Christopher. 1977. "The Effect of Political Democracy and Social Democracy on Equality in Industrial Societies: A Cross-National Comparison." American Sociological Review 42: 450-64.

Hsiao, Cheng. 1986. Analysis of Panel Data. New York: Cambridge University Press.

Huber, Evelyne, and John D. Stephens. 2000. " Partisan Governance, Women's Employment and the Social Democratic Service State." American Sociological Review 65: 323-42.

2001. Development and Crisis of the Welfare State: Parties and Policies in Global Markets. Chicago: University of Chicago Press.

Huber, Evelyne, Charles Ragin, and John D. Stephens. 1997. Comparative Welfare States Data Set, Northwestern University and University of North Carolina. (http://lissy.ceps.lu/compwsp.htm).

1993. "Social Democracy, Christian Democracy, Constitutional Structure and the Welfare State." American Journal of Sociology 99: 711-49.

Iversen., Torben.. 1996. "Power, Flexibility and the Breakdown of Centralized Wage Bargaining: The Cases of Denmark and Sweden in Comparative Perspective." Comparative Politics. 28 (July) 399-436.

1998. "Wage Bargaining, Central Bank Independence and the Real Effects of Money." International Organization 52 (3).

Korpi, Walter. 1983. The Democratic Class Struggle. London: Routledge and Kegan Paul.

Kuznets, Simon. 1955. "Economic Growth and Income Inequality." American Economic Review 45:1-28.

Lenski, Gerhard E. 1966. Power and Privilege: A Theory of Social Stratification. New York: McGraw-Hill.

Mäkinen, Tiina. 1998. "Contradictory Findings? The Connection Between Structural Factors, Income Transfers and Poverty in OECD Countries."

Mitchell, Deborah. 1991. Income Transfers in Ten Welfare States. Brookfield: Avebury.

Nielsen, François. 1994. "Income Inequality \& Industrial Development: Dualism Revisited." American Sociological Review 59:654-677.

Nielsen, François and Arthur S. Alderson. 1995. "Income Inequality, Development, \& Dualism: Results from an Unbalanced Cross-National Panel." American Sociological Review 60:674-701. 
Nielsen, François and Arthur S. Alderson. 1997. "The Kuznets Curve and the Great UTurn: Income Inequality in U.S. Counties, 1970 to 1990." American Sociological Review 62:12-33.

OECD. 1995. "Income Distribution in OECD Countries: Evidence from the Luxembourg Income Study." Social Policy Studies No. 18.

Paukert, F. 1973.

Pontusson, Jonas, David Rueda, and Chris Way. forthcoming. "Comparative political economy of wage distribution: The role of partisanship and labor market institutions," British Journal of Political Science.

Quinn, Dennis and Carla Inclan. 1997. "The Origins of Financial Openness: A 21 Country Study of Its Determinants, 1950-1988." American Journal of Political Science 41: 771-813.

Rueschemeyer, Dietrich, Evelyne Huber Stephens, and John D. Stephens. 1992. Capitalist Development and Democracy. Chicago: University of Chicago Press.

Sawyer, Malcolm. 1976. "Income Distribution in OECD Countries." Occasional Studies. Paris: OECD.

Simmons, Beth A. 1999. "The Internationalization of Capital." Pp. 36-70 in Herbert Kitschelt, Peter Lange, Gary Marks, and John D. Stephens (eds.). Continuity and Change in Contemporary Capitalism. New York: Cambridge University Press.

StataCorp. 1999. Stata Statistical Software: Release 6.0. College Station, TX: Stata Corporation.

Stephens, John. D. 1976. “The Consequences of Social Structural Change for the Development of Socialism in Sweden.” Ph. D. Dissertation, Yale University.

1979b. The Transition from Capitalism to Socialism. London: Macmillan.

Stimson, James A. 1985. Regression in Time and Space: A Statistical Essay." American Journal of Political Science 29: 914-47.

Thurow, Lester C. 1987. "A Surge in Inequality." Scientific American 256:(5):30-37.

Van Kersbergen, Kees. 1995. Social Capitalism: A Study of Christian Democracy and the Welfare State. London and New York: Routledge.

Wallerstein, Michael. 1999. Wage Setting Institutions and Pay Inequality in Advanced Industrial Societies. American Journal of Political Science 43: 649-80.

Wood, Adrian. 1994. North-South Trade, Employment, and Inequality. Oxford: Oxford University Press. 
TABLE 1

VARIABLES

\section{$\underline{\text { Dependent Variables }}$}

Pre Tax and Transfer Inequality: Pre tax/transfer gini index of income inequality among households with a head aged 25-59: \#

Post Tax and Transfer Inequality: Post tax/transfer gini index of income inequality among households with a head aged 25-59: \#

Reduction in Inequality: \% reduction in inequality effected by taxes and transfers [(1post inequality/pre inequality)x100]\#

Independent Variables

Taxes and Transfers: Welfare state generosity: summation of the standardized values of the following two indicators of welfare state effort Government revenue as a percentage of GDP $\left(\mathrm{HRS}^{*}, \mathrm{OECD}^{\circ}\right)$

Social security transfers as a percentage of GDP (HRS, OECD)

Left Cabinet: Scored 1 for each year when the left is in government alone, scored as a fraction of the left's seats in parliament of all governing parties' seats for coalition governments, 1946 to date (HRS).

Christian Democratic Cabinet: Religious parties' government share, coded as for left cabinet (HRS)

Constitutional Structure: Veto points created by constitutional provisions (HRS)

Union density: Union membership as a percentage of total wage and salary earners (HRS, Ebbinghaus and Visser 1992)

Bargaining Centralization: Degree of centralization of wage bargaining (Iversen 1998)

Female labor force participation: Percentage of women age 15 to 64 in the labor force (HRS, OECD)

\% Young: \% of the population under 15 years of age (HRS, OECD)

Unemployment: Percentage of total labor force unemployed (HRS, OECD)

Capital: Liberalness of capital controls (Quinn and Inclan 1997)

LDC Imports: Imports from non OECD countries as a \% of GDP

$\%$ in Industry: \% of the labor force in industrial employment (HRS, OECD)

* Data from the Huber, Ragin, and Stephens (1997) data set. The Huber, Ragin, and Stephens data set can be downloaded at http://www.lis.ceps.lu/compwsp.htm.

- Original data source is OECD.

- Data from the Welfare State Exit Entry Project, Science Center - Berlin

\#From Luxembourg Income Surveys. 
Table 2

Mean Values of Key Variables by Country

\begin{tabular}{|c|c|c|c|c|c|c|c|}
\hline $\begin{array}{l}\text { Pre Tax } \\
\& \text { Tranfer } \\
\text { Gini }\end{array}$ & $\begin{array}{c}\text { Post } \\
\& \text { Tranfer } \\
\text { Gini }\end{array}$ & $\begin{array}{l}\text { Reduction in } \\
\text { Gini due to } \\
\text { taxes \& tranfers }\end{array}$ & $\begin{array}{l}\text { Union } \\
\text { Density }\end{array}$ & $\begin{array}{l}\text { Bargaining } \\
\text { Centralization }\end{array}$ & $\begin{array}{l}\text { Left } \\
\text { Cabinet }\end{array}$ & $\begin{array}{c}\text { Christian } \\
\text { Democratic } \\
\text { Cabinet }\end{array}$ & $\begin{array}{l}\text { W } \\
\text { Gen }\end{array}$ \\
\hline
\end{tabular}

$\underline{\text { Social Democratic Welfare States }}$

\begin{tabular}{|c|c|c|c|c|c|c|c|c|}
\hline Sweden & 32.7 & 20.2 & 37.9 & 80 & .473 & 32 & 0 & 1.62 \\
\hline Norway & 29.8 & 21.5 & 27.5 & 55 & .506 & 32 & 2 & 1.61 \\
\hline Denmark & 32.5 & 21.5 & 33.6 & 72 & .355 & 25 & 0 & 1.98 \\
\hline Finland & 31.0 & 20.0 & 35.2 & 78 & .394 & 19 & 0 & 1.37 \\
\hline Mean & 31.5 & 20.8 & 33.6 & 71 & .432 & 27 & 1 & 1.65 \\
\hline \multicolumn{9}{|c|}{ Christian Democratic Welfare States } \\
\hline Belgium & 33.7 & 21.6 & 35.6 & 57 & .273 & 13 & 23 & 1.52 \\
\hline Netherlands & 37.5 & 26.0 & 30.6 & 26 & .382 & 10 & 28 & 3.10 \\
\hline Germany & 32.2 & 26.2 & 18.7 & 32 & .327 & 11 & 18 & 0.11 \\
\hline France & 39.4 & 29.4 & 25.4 & 12 & .142 & 7 & 4 & 1.17 \\
\hline Italy & 35.7 & 31.3 & 12.1 & 40 & .182 & 5 & 37 & 0.18 \\
\hline Switzerland & 33.5 & 30.5 & 8.8 & 26 & .249 & 11 & 12 & -1.75 \\
\hline Mean & 35.3 & 27.5 & 21.9 & 32 & .259 & 10 & 20 & 0.72 \\
\hline \multicolumn{9}{|c|}{$\underline{\text { Liberal Welfare States }}$} \\
\hline Australia & 37.5 & 28.5 & 24.0 & 40 & .399 & 12 & 0 & -2.54 \\
\hline Canada & 35.8 & 28.2 & 21.3 & 28 & .071 & 0 & 0 & -1.65 \\
\hline UK & 38.2 & 29.3 & 22.7 & 40 & .122 & 15 & 0 & -1.37 \\
\hline USA & 39.8 & 32.8 & 17.6 & 17 & .071 & 0 & 0 & -2.44 \\
\hline Mean & 37.8 & 29.7 & 21.4 & 31 & .166 & 7 & 0 & -2.00 \\
\hline
\end{tabular}


Table 3

Determinants of Pre Tax and Transfer Inequality

\begin{tabular}{|c|c|c|c|c|c|c|c|c|c|c|c|c|}
\hline & \multicolumn{2}{|c|}{$\begin{array}{l}\text { Controls } \\
\text { Only }\end{array}$} & \multicolumn{2}{|c|}{$\begin{array}{c}\text { Labor Market } \\
\text { Institutions }\end{array}$} & \multicolumn{2}{|c|}{$\begin{array}{l}\text { Political } \\
\text { Variables }\end{array}$} & \multicolumn{2}{|c|}{ Combined } & \multicolumn{2}{|c|}{ Reduced } & \multicolumn{2}{|c|}{$\begin{array}{l}\text { Alternatives } \\
\text { to GDP per capita }\end{array}$} \\
\hline & $\mathrm{b}$ & $\beta$ & $\mathrm{b}$ & $\beta$ & $\mathrm{b}$ & B & $\mathrm{b}$ & $\beta$ & $\mathrm{b}$ & B & $\mathrm{b}$ & B \\
\hline GDP per capita & $.239^{\circ}$ & .29 & & & & & $.289 * *$ & .35 & $.351 * *$ & .43 & & \\
\hline Unemployment & $.542^{\circ}$ & .39 & & & & & $.572 * *$ & .41 & $.504 * *$ & .37 & $.347^{\circ}$ & .25 \\
\hline Female labor force participation & -.060 & -.13 & & & & & & & & & & \\
\hline$\%$ Young & $.820 * *$ & .48 & & & & & $.449 * *$ & .26 & $.425 * *$ & .25 & .251 & .15 \\
\hline Capital Market Openness & 1.122 & .16 & & & & & & & & & 1.078 & .15 \\
\hline$\%$ in Industry & .110 & .15 & & & & & & & & & -.174 & -.23 \\
\hline LDC Imports & 30.501 & .05 & & & & & & & & & 89.817 & .16 \\
\hline Union Density & & & $-.075 *$ & -.35 & & & $-.119 *$ & -.55 & $-.076 *$ & -.35 & $-.087 *$ & -.41 \\
\hline Bargaining Centralization & & & $-7.503^{\circ}$ & -.26 & & & -4.930 & -.18 & & & & \\
\hline Left Cabinet & & & & & $-.197 *$ & -.46 & .164 & .37 & & & & \\
\hline Christian Democratic Cabinet & & & & & -.080 & -.19 & & & & & & \\
\hline Constitutional Structure & & & & & .153 & .06 & & & & & & \\
\hline Taxes and Transfers & & & & & .460 & .18 & & & & & & \\
\hline Constant & 1.944 & & $40.345 * *$ & & $38.173 * *$ & & $22.281 * *$ & & $21.443 * *$ & & $30.957 * *$ & \\
\hline $\begin{array}{l}\text { R-Square } \\
\text { b - unstandardized coefficient } \\
B \text { - standardized coefficient } \\
\text { Level of significance: } * *=.01, * \\
N=61\end{array}$ &,$^{\circ}=.1$ & & 0.30 & & .14 & & .62 & & .58 & & .56 & \\
\hline
\end{tabular}


Table 4

Determinants of Government Reduction in Inequality

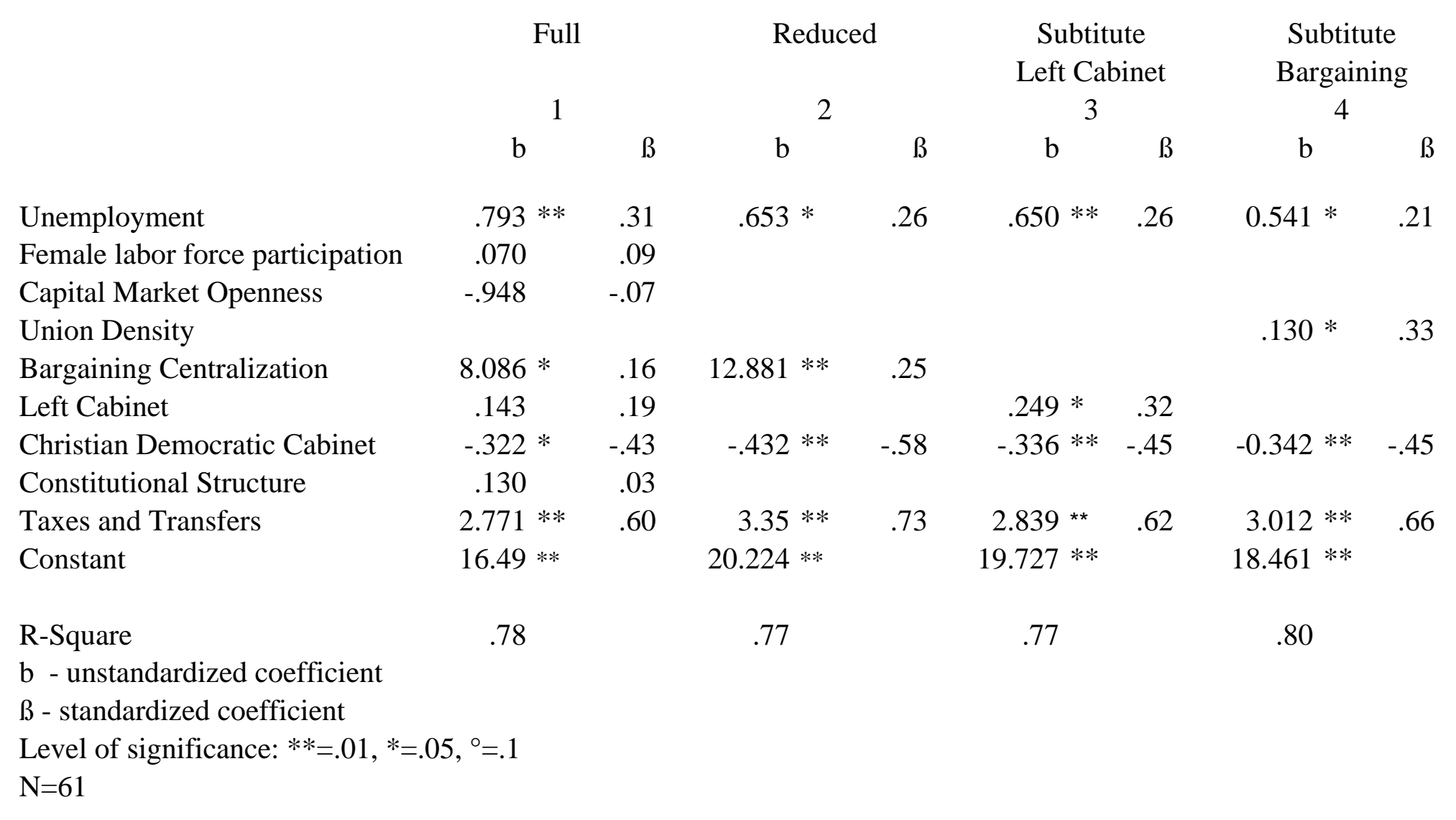


Figure 1

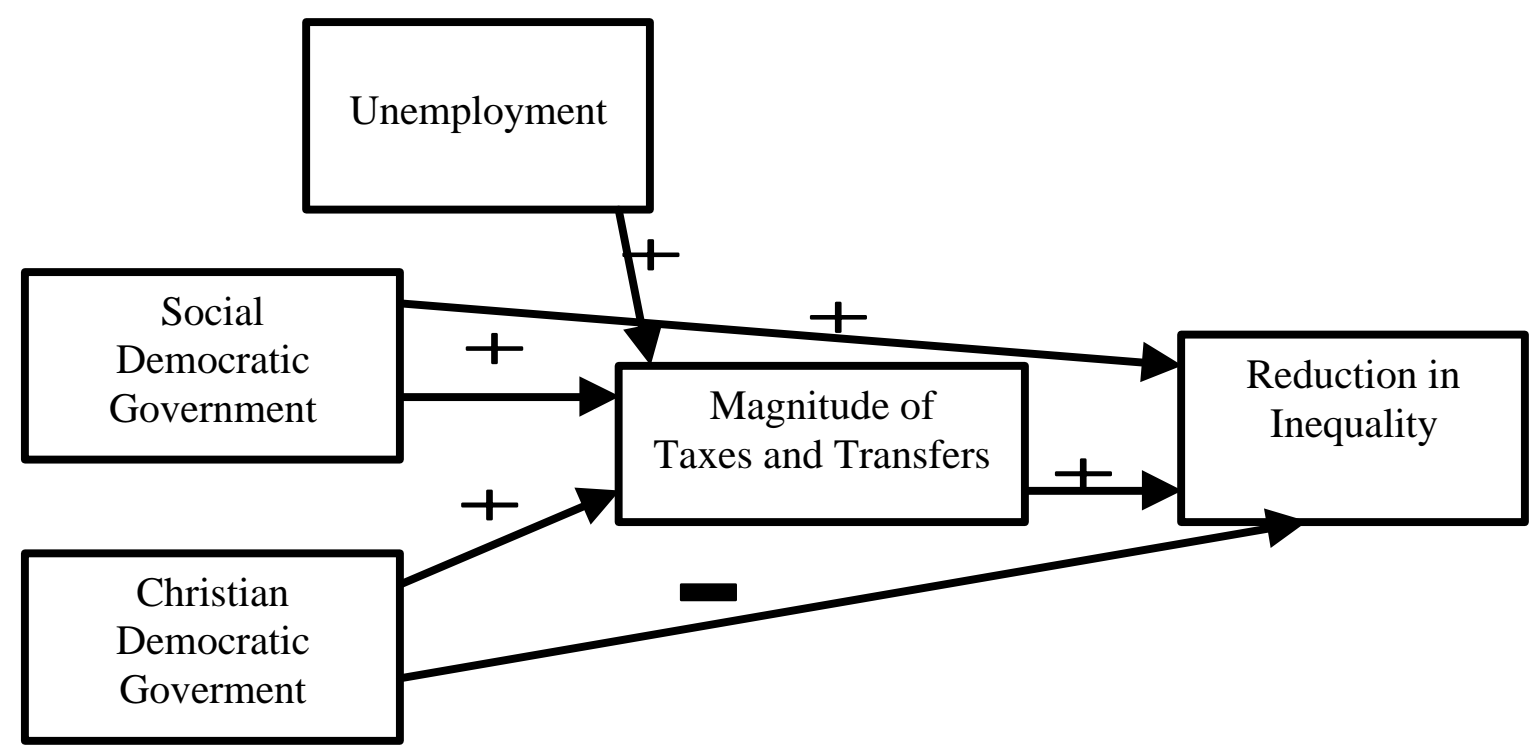

